\title{
MENINGKATKAN KEMAMPUAN MOTORIK HALUS ANAK MELALUI KEGIATAN MELUKIS DENGAN TEHNIK FINGER PAINTING DI TK NEGERI I PEMBINA MEDAN
}

\author{
Rahmi Bachtar \\ Surel: rahmi27091966@gmail.com
}

\begin{abstract}
The purpose of this class action research is to improve the fine motor skills of children through painting activities using the technique of pinger paenting in the BTK class of Pembina 1 Medan, Jln. Ujung Karya Medan City. The subjects in this class action research were class $B$ kindergarten children which numbered 15 people consisting of 9 female students and 6 male students. The data collection technique used in this study is to use quantitative data in the form of tests and qualitative data in the form of observations. The observation shows that in the first cycle the teacher (researcher) has been able to improve the fine motor skills of the child by painting with the pinger paeting technique in fine motor learning activities well (35\%) and in cycle II the teacher (researcher) can apply to improve fine motor skills in painting with the technique of pinger paenting very well (80\%). In the first cycle students 'activities were classified into sufficient categories, while in the second cycle students' activities increased and were classified in the good category.
\end{abstract}

Keywords: Fine motoric children, Painting, Finger Technique Painting

\begin{abstract}
ABSTRAK
Tujuan Penelitian tindakan kelas ini adalah untuk meningkatkan motorik halus anak melalui kegiatan melukis dengan teknik finger painting di kelas BTK Negeri pembina 1 Medan Jln. Karya Ujung Kota Medan. Subjek dalam penelitian tindakan kelas ini adalah anak taman kanak-kanak kelas B yang berjumlah 15 orang yang terdiri dari 9 siswa perempuan dan 6 siswa laki-laki. Teknik pengumpulan data yang digunakan dalam penelitian ini adalah dengan menggunakan data kuantitatif berupa test dan data kualitatif berupa observasi. Hasil observasi menunjukkan bahwa pada siklus I guru (peneliti) sudah dapat meningkatkan kemampuan motorik halus anak dengan kegiatan melukis dengan teknik pinger paeting dalam kegiatan pembelajaran motorik halus dengan baik (35\%) dan pada siklus II guru (peneliti) dapat menerapkan meningkatkan kemampuan motorik halus dalam kegiatan melukis dengan teknik pinger paenting dengan sangat baik (80\%) . Pada siklus I aktivitas siswa digolongkan dalam kategori cukup, sedangkan pada siklus II aktivitas siswa meningkat dan digolongkan dalam kategori baik.
\end{abstract}

Kata Kunci : Motorik halus anak, Melukis, Tehnik Finger painting

\section{PENDAHULUAN}

Keterampilan motorik adalah keterampilan alami yang akan digunakan seumur hidup. Namun, demikian anak usia dini harus difasilitasi dan dilatih secara kontiniu untuk mengembangkan keterampilan motoriknya. Anak yang memiliki keterampilan motorik yang baik akan mudah mempelajari hal-hal baru yang bermanfaat dalam menjalani pendidikan. 
Dimana anak dapat melakukan kegiatan seperti: menggunting kertas dengan hasil guntingan yang lurus, membuat gambar sederhana, mewarnai, menjahit, menganyam sederhana, dan menajamkan pinsil dengan rautan pensil. Namun, tidak semua anak memiliki kematangan pada tahap yang sama karena faktor yang diantaranya latihan yang kurang (Haldayani, 2004: 8. 15). Pembelajaran melukis menggunakan jari atau finger painting memiliki tujuan yaitu mengembangkan ekspresi melalui media melukis dengan gerakan tangan, mengembangkan fantasi, imajinasi, kreasi, melatih otot-otot tangan/jari, koordinasi mata-tangan, melatih kecakapan, mengkombinasi warna, memupuk perasaan terhadap gerakkan tangan, memupuk perasaan indah (Montolulu, 2004: 3.17). Adapun tujuan lain yang di kemukakan oleh Pamadhi (2008: 3.36) yaitu, melatih motorik anak yang melibatkan gerak otot-otot kecil dan kematangan syaraf, serta mengenal konsep warna primer (merah, kuning, biru). Manfaat yang didapat dari aktifitas melukis diantaranya adalah sebagai media mengungkapkan perasaannya sebagai alat bercerita, sebagai alat untuk bermain, melatih berfikir menyeluruh (Pamadhi, 2008: 3.10).

Pembelajaran melukis yang dilakukan di TK Negeri Pembina 1 Jln. Karya Ujung Medan dengan memperhatikan hasil dari proses kegiatan menunjukkan perlu adanya variasi dan metode yang ditentukan alat peraga/media yang diberikan sebagai usaha untuk memotivasi anak agar dapat melakukan kegiatan sesuai dengan hasil dan tujuan yang diharapkan.

Peneliti menyadari ada hal penting yang menjadi masalah di tempat peneliti mengajar pada kelompok B TK Negeri Pembina 1 Jln. Karya Ujung Medan yaitu anak didik sebagian besar belum mampu melaksanakan kegiatan melukis dengan teknik finger painting. Hal ini dibuktikan dengan tidak memuaskannya hasil karya anak pada kegiatan pengembangan motorik halus anak tersebut.

\section{METODE PENELITIAN}

Penelitian ini adalah penelitian Tindakan Kelas (clasroom Riset) di lakasanakan selama dua siklus.Subjek penelitian adalah murid di kelompok B TK Negeri Pembina 1 Jln. Karya Ujung Medan yang berjumlah 15 orang, dengan anak laki-laki 6 orang dan anak perempuan 9 orang. Penelitian ini dilakukan di TK Negeri Pembina 1 Jln. Karya Ujung Kota medan Sumatera Utara. Data penelitian tindakan yang dikumpulkan berupa informasi-informasi tentang kemampuan siswa dalam melukis dengan finger painting. Metode pengumpulan data merupakan usaha sadar untuk mengumpulkan data yang dilaksanakan secara sistematisdengan prosedur yang standar". Suharsimi Arikunto (2002: 1997). Tehnik pengumpulan data 
dalam penelitian ini adalah observasi dan wawancara yang di lakukan terhadap sumber data. Sedangkan alat untuk pengumpul data menggunakan kamera dan dokumen resmi data anak yang terlibat dalam penelitian.

Penelitian ini adalah Penelitian Tindakan Kelas (PTK) dimana pengkajian siklus yang terdiri dari empat tahap yaitu: (1) perencanaan, (2) pelaksanaan, (3) pengamatan, dan (4) refleksi.

Adapun prosedur pelaksanaan penelitian tindakan kelas ini adalah dengan membuat Rencana Pelaksanaan Pembelajaran Harian sesuai dengan indikator yang akan dicapai. Setelah kegiatan pembelajaran dilaksanakan, maka dilakukan evaluasi terhadap pelaksanaan pembelajaran, kemampuan anak, maupun pembelajaran yang telah dilakukan guru dalam hal ini peneliti.

Setelah evaluasi dilakukan, peneliti bersama-sama dengan observer melakukan refleksi dan diskusi tentang masalah-masalah yang ditemukan selama kegiatan pembelajaran berlangsung. Selama kegiatan pembelajaran berlangsung observer sebagai teman kolaborator mengamati, menilai dan memberi bimbingan kepada guru dalam melakukan rancangan kegiatan pembelajaran. Manakala dalam refleksi telah ditemukan masalah pembelajaran menjadi penghambat kemajuan anak, maka peneliti dan observer bersama-sama mengambil masalah yang akan dipecahkan dalam siklus 1. Dalam hal ini yang menjadi fokus guru dalam memecahkan masalah yang sedang terjadi ini adalah bagaimana upaya guru untuk memudah dalam melukis dengan tehnik finger painting. Maka direncanakanlah langkah-langkah pembelajaran yang dilakukan oleh guru untuk meningkatkan kemampuan motorik halus anak melukis dengan tehnik finger painting.

Pada tahap ini observasi dilakukan secara langsung dengan memakai format observasi yang telah disusun serta melakukan penilaian terhadap hasil tindakan ketika berlangsungnya pembelajaran, penilaian dalam hal ini bertindak sebagai pengamat melakukan pengamatan dan pencatatan yang terjadi selama kegiatan baik kepada guru maupun siswa.

Validitas data yang digunakan antara lain dengan triangulasi sumber data dan triangulasi metode pengumpulan data. Dalam penelitian ini teknik triangulasi untuk mengetahui kesulitan yang dihadapi siswa dalam kemampuan membaca kata dalam pengembangan bahasa dan faktor penyebabnya. Untuk itu peneliti membandingkan data hasil penelitian dari berbagai metode antara lain dengan tes, observasi dan dokumentasi.

Menurut Sarwiji Suwandi (2008: 70) "teknik analisis yang digunakan untuk menganalisis data-data yang telah berhasil dikumpullkan antara lain dengan teknik deskriptif (statsitik deskriptif) dan teknik 
analisis kritis. Teknik deskriptif digunakan untuk data kuantitatif, sedangkan teknik analisis kritis berkaitan dengan data kualitatif". Analisis data dilakukan melalui teknik pengumpulan data yaitu melalui observasi dan interprestasi yang dilakukan bersama dengan pelaksanaan tindak perbaikan. Interprestasi dilakukan untuk menginteprestasi data. Analisis data dilakukan secara kualitatif-deskriftif untuk menemukan persentase dan nilai rata-rata. Penyajian hasil analisis data dilakukan dengan membuat tabel distribusi atau grafik. Setelah analisis data diperoleh kemudian interprestasikan data tersebut sehingga akan memudahkan guru dalam melakukan tindakan perbaikan yang lebih baik lagi.

Nilai akhir rata-rata yang diperoleh anak menggunakan rumus:

Keterangan :

$$
\bar{x}=\frac{\sum X}{N}
$$

$\bar{x}=$ Nilai Akhir Rata-rata anak

$\Sigma \mathrm{X}=$ Jumlah Nilai akhir anak

$\mathrm{N}=$ Jumlah anak

Ketuntasan belajar secara klasikal dihitung dengan menggunakan rumus:

(Suharsimi, 1987)

$$
P=\frac{n}{N} x 100 \%
$$

Keterangan :

$\mathrm{P} \quad=$ Tingkat Kemampuan

$\mathrm{n} \quad=$ Jumlah nilai anak yang diperoleh dari data

$\mathrm{N} \quad=$ Jumlah anak

$100 \%=$ Nilai Konstan

\section{HASIL PENELITIAN DAN PEMBAHASAN}

Pada bagian ini, Deskripsi hasil data meliputi data tentang rencana pelaksanaan pengamat dan refleksi pada tindakan perbaikan siklus 1 yaitu:

a. Melaksanakan kemampuan fisik motorik halus anak melalui kegiatan melukis dengan teknik finger painting sesuai dengan materi yang diawali dengan kegiatan bernyanyi dan bertanya jawab sesuai dengan materi yang akan diajarkan. Agar siswa terdorong mengikuti kegiatan pembelajaran.

b. Mengelola kelas secara menyeluruh, yaitu menciptakan suasana kelas yang gembira dan ceria.

c. Menyiapkan media dan sumber belajar.

d. Memberikan reward atas hasil karya anak sehingga dapat memotivasi anak untuk melakukan kegiatan finger painting.

e. Guru membuat skenario perbaikan secara rinci.

\section{Langkah-langkah pelaksanaan} yang dilakukan guru pada proses pembelajaran adalah sebagai berikut:

a. Guru melakukan kegiatan pembukaan yang dapat menyenangkan anak.

b. Guru memberikan gambaran yang akan dilakukan dalam melukis. 
c. Anak mengamati alat dan bahan yang akan digunakan untuk melukis.

d. Anak dan guru melakukan tanya jawab seputar bahan yang akan digunakan untuk melukis.

e. Guru membagi bahan dan alat untuk melukis ke pada anak

f. Guru menjelaskan kegiatan yang akan dilakukan pada anak yaitu melukis dengan tehnik finger painting.

g. Guru memperagakan cara melukis dengan tehnik finger painting dengan menggunakan playdogh yang di buat sendiri dan memperlihatkan media yang telah dibuat guru sebagai contoh pada anak untuk melakukan kegiatan.

h. Anak mengerjakan kegiatan finger painting dengan menggunakan mediya playdogh pada lembar kerja yang telah disediakan.

Berdasarkan hasil observasi
yang dilakukan oleh sepervisor,
ditemukan hal-hal yang terjadi
selama perbaikan pembelajaran
yaitu:

a. Kegiatan pembelajaran berlangsung seperti yang diharapkan.

b. Ada beberapa anak yang mampu mengerjakan kagiatan melukis dengan teknik finger painting dengan sangat baik.

c. Ada juga anak yang belum berkembang kemampuan motorik halusnya. Hal ini terlihat anak tidak dapat menggerakan jarinya diatas kertas yang telah disediakan oleh guru.

Dari 15 orang jumlah siswa yang terlibat dalam penelitian, hanya 7 berkembang sesuai harapan, 4 orang yang mulai berkembang, dan 4 orang yang belum berkembang dari indikator pencapaian perkembangan dan belum ada yang berkembang sangat baik maka perlu dilanjutkan ke siklus II.

Berdasarkan hasil refleksi, peneliti memutuskan untuk mengadakan perbaikan karena hasil kemampuan perkembangan motorik halus anak pada siklus pertama belum memenuhi target yang ditetapkan yaitu rata-rata 3 atau hanya sekitar 43\%. Adapun data deskripsi hasil data tentang rencana, pelaksanaan, pengamatan dan refleksi pada tindakan II adalah sebagai berikut:

a. Rencana perbaikan telah disusun berdasarkan akademis, sarana, prasarana dan fasilitas. Pengelolaan kelas sama seperti siklus I yaitu dengan modal kelompok.

b. Guru melaksanakan kegiatan melukis dengan teknik finger painting dengan memberikan 2-3 macam warna agar menarik perhatian anak.

c. Guru membuat skenario perbaikan pembelajaran yang telah ditetapkan sebagai hasil refleksi kegiatan siklus I. 
Langkah-langkah yang
dilakukan guru pada proses
pembelajaran adalah sebagai berikut:

a. Guru tetap melakukan motivasi terhadap anak.

b. Guru memberikan gambaran yang akan dilakukan dalam melukis dengan tehnik finger painting.

c. Guru melakukan tanya jawab pada anak gambar apa yang akan dilukis hari ini.

d. Guru membagikan ke anak alat dan bahan yang akan dilukis

e. Guru memberikan penjelasan tentang cara melakukan kegiatan melukis dengan teknik finger painting.

f. Guru menunjukkan media kegiatan melukis dengan teknik figer painting yang telah dibuat guru yang menjadi target perbaikan serta mencontohkan cara mengerjakannya.

g. Siswa mengerjakan kegiatan melukis dengan teknik finger painting pada lembar kerja yang telah disediakan guru dan anak diperintahkan bebas berkreasi pada hasil karyanya.

h. Guru memberikan pujian pada anak yang telah berhasil mengerjakan dengan baik.

Berdasarkan hasil observasi yang dilakukan oleh peneliti dan teman sejawat, ditemukan hal-hal yang terjadi selama perbaikan yaitu:

a. Kegiatan pembelajaran berlangsung dengan tertib

b. Hampir seluruh anak mampumengerjakan kegiatan melukis dengan teknik finger painting dengan sangat baik.

c. Ada 2 orang anak yang belum berkembang kemampuan motorik halusnya namun sudah ada kemajuan dari belum berkembang menjadi mulai berkembang. Hal ini terlihat anak cukup mampu mengkoordinasikan antara tangan dengan matanya.

d. Beberapa anak meminta warna lain untuk mengerjakan kegiatan melukis dengan teknik finger painting lagi untuk membuat kreasi yang lain.

Berdasarkan pada hasil observasi teman sejawat dan penilaian dari supervisor serta hasik refleksi dari keseluruhan proses dan analisis dari hasil belajar dan kegiatan siswa. Maka dapat diambil keputusan bahwa tidak perlu lagi dilakukan perbaikan lanjutan karena perbaikan siklus II telah memenuhi target atau telah dicapai. Dengan demikian peneliti, teman sejawat serta supervisor sepakat bahwa perbaikan siklus III tidak perlu dilakukan.

Adapun hasil kerja siswa dapat dilihat pada analisis hasil penilaian siklus II kegiatan pembelajaran yang dilakukan anak. Berdasarkan pada hasil observasi teman sejawat dan penilaian dari observer serta hasil refleksi dari keseluruhan proses dan analisis dari hasil belajar dan kegiatan anak maka rata-rata perkembangan motorik halus anak mencapai 87\%. Maka 
dapat diambil keputusan bahwa tidak perlu lagi dilakukan perbaikan lanjutan karena perbaikan pada siklus II telah memenuhi target atau telah berhasil yaitu sudah melebihi indikator kinerja yang ditentukan (70\%). Pencapaian kemampuan motorik halus siswa pada siklus I setelah diterapkan kegiatan melukis dengan teknik finger painting.

\section{Grafik 1. Pencapaian Kemampuan kegiatan melukis}

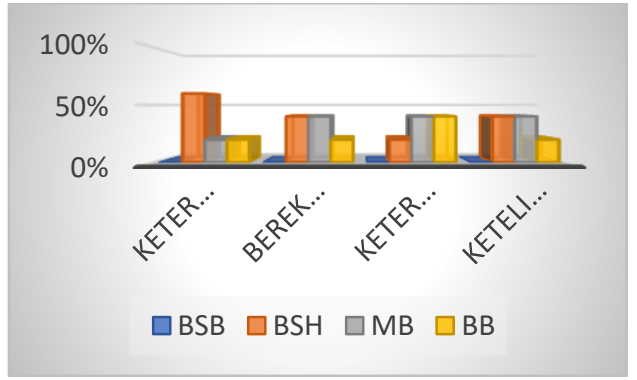

Menurut data dari penilaian grafik diatas terlihat bahwa kemampuan dalam keterampilan menggunakan jari jemari keberhasilannya hanya mencapai 60\%, Tanggung Jawab keberhasilannya mencapai 20\%, Kesesuaian dalam memilih warna hanya $40 \%$, serta dalam Kerapian dan kebersihan dalam bekerja keberhasilannya hanya 20\%. Jadi secara keseluruhan pelaksanaan perbaikan belum berhasil karena keberhasilan anak dididk hanya mencapai $35 \%$.

\section{Pembahasan}

Secara umum perbaiakan pada siklus II menunjukan hasil yang memuaskan. Adapun hal-hal penting yang akan dibahas pada siklus ii adalah sebagai berikut:

a. Kegiatan pembelajaran berlangsung dengan tertib dan menyenangkan. Hal ini dapat tercapai karena usaha guru membarikan motivasi dan menyediakan media pembelajaran yang menarik minat siswa sehingga siswa yang tidak mau mengerjakan kegiatan melukis dengan teknik finger painting manjadi mau mengerjakannya.

b. Hampir seluruh anak mampu mengerjakan kegiatan melukis dengan teknik finger painting dengan sangat baik. Hal ini terjadi karena media yang digunakan siswa menarik dan berwarna-warni sehingga siswa asyik mengerjakannya.

c. Ada 1 orang anak yang belum berkembang kemampuan motorik halusnya namun sudah ada kemajuan dari belum berkembang menjadi mulai berkembang. Hal ini terlihat siswa cukup mampu menggerakan jari-jemarinya dengan lentur.

d. Beberapa anak meminta kertas untuk mengerjakan kegiatan melukis dnegan teknik finger painting lagi membuat kreasi yang lain. Hal ini terjadi karena anak sangat menikmati/bangga akan hasil karyanya sehingga siswa ingin menunjukan keahliannya dengan membuat karya yang lain lagi dan lagi. 
e. Hasil penilaian kegiatan dari 5 orang siswa secara keseluruhan.

\section{Grafik 2. Pencapaian kemampuan motorik halus siswa pada siklus II setelah diterapkan kegiatan melukis dengan teknik finger painting}

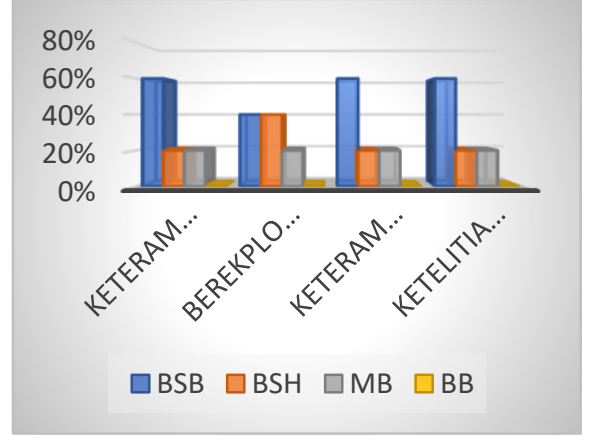

Berdasarkan data dari penilaian grafik diatas terlihat bahwa kemampuan dalam keterampilan menggunakan jari jemari dengan kriteria Berkembang Sesuai Harapan dan Berkembang Sangat Baik keberhasilannya telah mencapai $80 \%$ keterampilan menggunakan jari jemari, $80 \%$ dalam berekplorasi dengan media yang disediakan, $80 \%$ keterampilan dalam memilih warna, 80\% ketelitian dan kebersihan dalam bekerja. Jadi secara keseluruhan pelaksanaan perbaikan pada siklus II telah berhasil dengan perolehan keberhasilan siswa didik mencapai $80 \%$.

Hal ini berarti bahwa melalui kegiatan melukis dengan teknik finger painting, perkembangan fisik motorik halus siswa dapat digali dan ditingkatkan dengan optimal. Hal ini terbukti dari tahapan siklus yang memperlihatkan bahwa pencapaian kemampuan motorik halus anak setelah diterapkan kegiatan melukis dengan teknik finger painting di kelas B TK Negeri Pembina Medan mengalami perkembangan rata-rata pada siklus I adalah 35\% dan pada siklus II adalah $80 \%$ yang dapat dilihat pada grafik 3 dibawah ini:

\section{Grafik 4.3 Pencapaian kemampuan motorik halus anak setelah diterapkan kegiatan melukis dengan teknik finger painting}

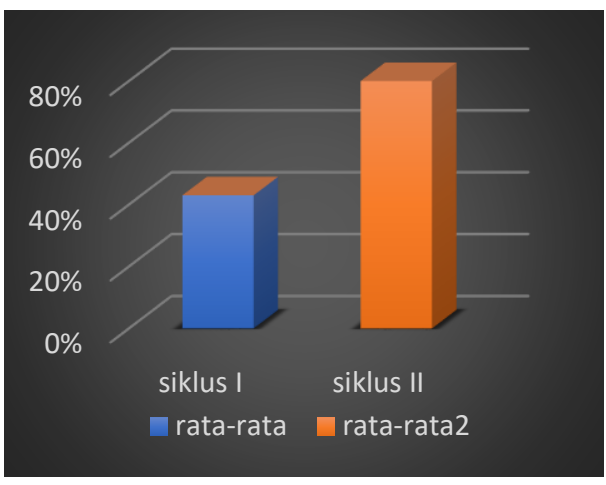

\section{SIMPULAN}

Berdasarkan hasil penelitian dalam pembahasan tentang upaya meningkatkan perkembangan kemampuan fisik motorik halus siswa tunagrahita sedang melalui kegiatan melukis dengan teknik finger painting di kelas B TK Negeri Pembina $1 \mathrm{Jln}$. Karya Ujung Medan dapat disimpulkan bahwa: 1). Perkembangan fisik motorik halus siswa di kelas B TK Negeri Pembina 1 Jln. Karya Ujung Medan sebelum diterapkan kegiatan melukis dengan teknik finger painting masih belum optimal kematangannya. Hal ini dapat terlihat dari capaian perkembangan siswa dalam keterampilan menggunakan jarijemari, koordinasi tangan dengan 
mata, ketelitian dalam bekerja serta dalam melatih otot-otot jari dan tangan masih dibawah rata-rata yang diharapkan yaitu rata-rata 2, sedangkan rata-rata yang diharapkan dapat dicapai siswa yaitu rata-rata 3. 2). Penerapan kegiatan melukis dengan teknik finger painting di kelas B TK Negeri Pembina 1 Jln. Karya Ujung Medan untuk meningkatkan perkembangan fisik motorik halus siswa tunagrahita sedang dapat berjalan sesuai perencanaan dan sangat efektif. Hal ini dapat dilihat dari kemampuan siswa pada siklus I yang mencapai $35 \%$ dan pada siklus II yang mencapai $80 \%$. Artinya tingkat perkembangan fisik motorik anak mengalami kemajuan. 3). Adapun cara meningkatkan perkembangan fisik motorik halus anak tunagrahita sedang di kelas B TK Negeri Pembina $1 \mathrm{Jln}$. Karya Ujung Medan dengan optimal seperti yang diharapkan yang dilakukan peneliti yaitu dengan menerapkan kegiatan melukis dengan teknik finger painting.

\section{DAFTAR RUJUKAN}

Brandt, Ann Mery. 2002. Mengenal Ragam Dan Jenis Finger Painting. Jakarta: Pusat Penerbit Universitas

Terbuka.

Down. 2008. Finger Painting Sebagai Media Pengekspresian Diri. Jakarta: Balai Pustaka.

Firman. 2010. Tahapan Dalam Melukis. Jakarta: Universitas Terbuka.
Lim, Imandala. 2007. Finger Painting

Mengembangkan Motorik Halus Pada Anak. Jakarta: Pusat Penerbit Universitas Terbuka.

Montolulu. 2004. Manfaat Dan Tujuan Finger Painting Pada Anak Usia Dini. Jakarta: Pusat Penerbit Universitas Terbuka Pamadhi, Hajar. 2010. Melukis Ekspresi. Jakarta: Universitas Terbuka.

Siti, Aisyah, dkk. 2009. Perkembangan dan Konsep Dasar Pengembangan Anak, Jakarta: Pusat Penerbit Universitas Terbuka. 